\title{
Pollen, water, and wind: Chaotic mixing in a puddle of water
}

\author{
Kaare H. Jensen* \\ Department of Physics, Technical University of Denmark, DK-2800 Kgs. Lyngby, Denmark \\ (Received 11 August 2016; published 12 September 2016) \\ This paper is associated with a poster winner of a 2015 APS/DFD Gallery of Fluid \\ Motion Award. The original poster is available from the Gallery of Fluid Motion, \\ http://dx.doi.org/10.1103/APS.DFD.2015.GFM.P0014
}

DOI: 10.1103/PhysRevFluids.1.050507

Water puddles are ubiquitous and provide a habitat for a vast array of living organisms, for instance, as breeding grounds for mosquitoes of the genus Anopheles that transmit malaria,



FIG. 1. Photograph of pine pollen grains dispersed in an approximately $1 \mathrm{~m}$ wide and $1 \mathrm{~cm}$ deep water puddle. The pollen has mixed due to wind blowing across the liquid surface. The photograph was taken at the Harvard University Biological Laboratories' parking lot on 2 June 2012, in Cambridge, Massachusetts, USA. For the poster associated to this image see http://dx.doi.org/10.1103/APS.DFD.2015.GFM.P0014

\footnotetext{
*khjensen@fysik.dtu.dk
}

Published by the American Physical Society under the terms of the Creative Commons Attribution 3.0 License. Further distribution of this work must maintain attribution to the author(s) and the published article's title, journal citation, and DOI. 
KAARE H. JENSEN

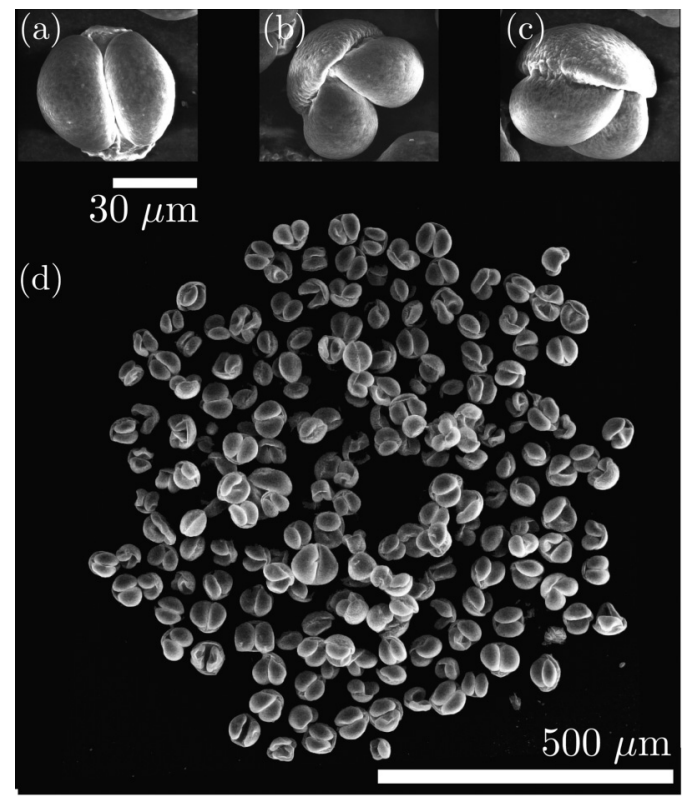

FIG. 2. Scanning electron micrographs of pine pollen. Closeup images (a)-(c) highlight the two air-filled bladders which are believed to increase dispersal distance and help orient the pollen in the pollination droplet [5]. The circular deposition pattern in (d) was formed by an evaporating droplet. Images courtesy of Katrine S. Haaning and Niklas M. Secher, Department of Physics, Technical University of Denmark.

a disease responsible for 214 million cases and 438000 deaths in 2015 [1]. The mosquito larvae feed on algae and bacteria in the surface layer. However, flow dynamics and nutrient distribution patterns in water puddles remain poorly understood.

The photograph (Fig. 1) shows how pine pollen grains have dispersed in an approximately $1 \mathrm{~m}$ wide and $1 \mathrm{~cm}$ deep water puddle. The pollen has mixed due to wind blowing across the liquid surface, revealing a strikingly complex flow pattern. The flows revealed by nature's tracer particles may influence circulation and nutrient distribution in puddles and small ponds.

The flow patterns in Fig. 1 are generated by wind blowing across the puddle surface. This causes a shear stress at the atmospheric interface, which drives a flow in the liquid below. Chaotic mixing can occur if the wind direction changes over time [2]. A fluid patch is repeatedly stretched and folded into itself, resulting in a drastic reduction of the length over which molecules have to diffuse.

Pollen from pine trees was unusually abundant in 2012 when the photograph was taken, due to a largely dry spring which brought more than usual [3]. Pine pollen (Fig. 2) is winged, and typically measures $\sim 50 \mu \mathrm{m}$ in diameter. Pollen is transferred from a pollen cone to the ovule by wind or insects, and produces male sperm cells [4].

[1] WHO, "Malaria, fact sheet No. 94" (2016) (accessed 10 August 2016).

[2] C. Kranenburg, Wind-driven chaotic advection in a shallow model lake, J. Hydraul. Res. 30, 29 (1992).

[3] A. Matos and C. A. Young (Boston Globe), "Pollen in Boston, suburbs wears on residents' health, patience" (2012) (accessed 10 August 2016).

[4] M. Hesse, H. Halbritter, M. Weber, R. Buchner, A. Frosch-Radivo, S. Ulrich, and R. Zetter, Pollen Terminology: An Illustrated Handbook (Springer, Berlin, 2009).

[5] A. B. Schwendemann, G. Wang, M. L. Mertz, R. T. McWilliams, S. L. Thatcher, and J. M. Osborn, Aerodynamics of saccate pollen and its implications for wind pollination, Am. J. Bot. 94, 1371 (2007). 